\title{
Systematic Review \\ The Incidence and Treatment Response of Double Expression of MYC and BCL2 in Patients with Diffuse Large B-Cell Lymphoma: A Systematic Review and Meta-Analysis
}

\author{
Jisun Hwang ${ }^{1}{ }^{\circledR}$, Chong Hyun Suh ${ }^{2, *}$, Kyung Won Kim ${ }^{2}$, Ho Sung Kim ${ }^{2}$, Austin I. Kim ${ }^{3}$, Jeffrey W. Craig ${ }^{4}(\mathbb{D}$, \\ Ke Xun Chen ${ }^{5}{ }^{\circledR}$, Joel Roberson ${ }^{5}$, Jeffrey P. Guenette ${ }^{5,+}$ and Raymond Y. Huang ${ }^{5,+}$ \\ 1 Department of Radiology, Dongtan Sacred Heart Hospital, Hallym University Medical Center, 7, \\ Keunjaebong-gil, Hwaseong-si 18450, Gyeonggi-do, Korea; biydjs@hallym.or.kr \\ 2 Department of Radiology and Research Institute of Radiology, University of Ulsan College of Medicine, \\ Asan Medical Center, Olympic-ro 33, Seoul 05505, Korea; kyungwon_kim@amc.seoul.kr (K.W.K.); \\ radhskim@gmail.com (H.S.K.) \\ 3 Center for Hematologic Oncology, Dana-Farber Cancer Institute, Harvard Medical School, \\ Boston, MA 02115, USA; AustinI_Kim@dfci.harvard.edu \\ 4 Centre for Lymphoid Cancer, British Columbia Cancer, Vancouver, BC V5Z 4E6, Canada; \\ jeffrey.craig@bccancer.bc.ca \\ 5 Division of Neuroradiology, Brigham and Women's Hospital, Dana-Farber Cancer Institute, Harvard Medical \\ School, 75 Francis Street, Boston, MA 02115, USA; kexunchen@gmail.com (K.X.C.); Joel2r3@gmail.com (J.R.); \\ check for \\ updates \\ Citation: Hwang, J.; Suh, C.H.; Kim, \\ K.W.; Kim, H.S.; Kim, A.I.; Craig, J.W.; \\ JPGUENETTE@bwh.harvard.edu (J.P.G.); ryhuang@bwh.harvard.edu (R.Y.H.) \\ * Correspondence: chonghyunsuh@amc.seoul.kr; Tel.: +82-230-101-648 \\ + Both contribute equally.
} Chen, K.X.; Roberson, J.; Guenette, J.P.; Huang, R.Y. The Incidence and Treatment Response of Double Expression of MYC and BCL2 in Patients with Diffuse Large B-Cell Lymphoma: A Systematic Review and Meta-Analysis. Cancers 2021, 13, 3369. https://doi.org/10.3390/ cancers13133369

Academic Editors: Marcel Spaargaren and Alexandar Tzankov

Received: 11 April 2021

Accepted: 2 July 2021

Published: 5 July 2021

Publisher's Note: MDPI stays neutral with regard to jurisdictional claims in published maps and institutional affiliations.

Copyright: (C) 2021 by the authors Licensee MDPI, Basel, Switzerland. This article is an open access article distributed under the terms and conditions of the Creative Commons Attribution (CC BY) license (https:// creativecommons.org/licenses/by/ $4.0 /)$.
Simple Summary: Diffuse large B-cell lymphoma (DLBCL) with co-expression of MYC and BCL2 proteins is referred to as double expressor lymphoma. Multiple studies have identified double expressor status to be an adverse predictive factor for response to standard chemotherapy regimens. The revised 2016 WHO classification recommends cutoff values of $40 \%$ for MYC and $50 \%$ for BCL2 protein expression; however, actual cutoff values have varied widely among published studies. Increasing recognition of the potential prognostic value of double expressor status prompted this systematic review and meta-analysis of the worldwide literature. Our findings indicate that approximately 23\% of de novo DLBCL tumors express both MYC and BCL2 proteins above the indicated thresholds. Remarkably, different immunohistochemical cutoff values did not significantly affect the proportion of tumors attaining double expressor status. Cases lacking MYC/BCL2 co-expression were associated with a significantly higher probability of complete remission, thereby reaffirming the value of this predictive biomarker.

Abstract: MYC/BCL2 protein co-expression (i.e., double expressor) has been shown to be a negative predictor of outcome in diffuse large B-cell lymphoma (DLBCL). We aimed to establish the incidence of double expressor status in patients with de novo DLBCL and identify the predictive value of this biomarker on treatment response through systematic review and meta-analysis. PubMed and Embase were searched for studies published through December 2019 that reported proportions of double expressor DLBCL. The pooled proportions of MYC and BCL2 expression, both alone and in combination, were computed using the inverse variance method for calculating weights and by the DerSimonian-Laird method. The pooled odds ratios (ORs) of complete remission (CR) rate were calculated, and meta-regression analysis was conducted to explore heterogeneity. Forty-one studies (7054 patients) were included. The pooled incidence of double expressor status in DLBCL was $23 \%$ (95\% confidence interval [CI], 20-26\%), with an adjusted estimate of 31\% (95\% CI, 27-36\%). Neither MYC/BCL2 protein cutoff values, race, mean, or median age of included patients, or overall study quality was a significant factor of heterogeneity $(p \geq 0.20)$. Cases without double expressor status demonstrated a higher probability of $C R$ to rituximab, cyclophosphamide, doxorubicin, vincristine, and prednisone treatment (OR, 2.69; 95\% CI, 1.55-4.67). Our results reaffirm the predictive power of this important biomarker. 
Keywords: meta-analysis; systematic review; lymphoma; immunohistochemistry

\section{Introduction}

Diffuse large B-cell lymphoma (DLBCL) is the most common subtype of non-Hodgkin lymphoma [1]. The standard R-CHOP (rituximab, cyclophosphamide, doxorubicin, vincristine, and prednisone) chemotherapy regimen results in cure in up to $60 \%$ of patients [2]. A vigorous search has been made for biomarkers that can predict patients at high risk for treatment failure. Clinical and molecular factors including age, International Prognostic Index (IPI) score, molecular cell-of-origin (COO), chromosomal rearrangements, and protein expression have been identified as potential prognostic factors [3-6]. High-grade B-cell lymphoma with MYC and BCL2 and/or BCL6 rearrangements, so called double-hit and triple-hit (DH/TH) lymphomas, are defined in the 2016 World Health Organization (WHO) classification as a new diagnostic category and includes a subset of tumors with DLBCL morphology [7]. The concept of atypical DH lymphoma has also been proposed for cases harboring copy number variations in both MYC and/or BCL2 in the absence of concurrent translocations [8]. However, recent evidence shows that MYC and BCL2 copy number variations do not produce the high-risk gene expression signature seen in most true $\mathrm{DH} / \mathrm{TH}$ lymphomas harboring MYC and BCL2 rearrangements, suggesting that copy number variations should not be used to expand the definition of DH/TH lymphomas [9].

Expression of MYC and BCL2 proteins is identified by immunohistochemistry (IHC) in some patients with DLBCL even when the chromosomal rearrangements of $\mathrm{DH} / \mathrm{TH}$ lymphoma are not present. DLBCL tumors that co-express both MYC and BCL2 proteins (regardless of genetic rearrangement) are referred to as double expressor lymphomas. In the absence of chromosomal translocation, elevated protein expression is often mediated through alternative changes such as genetic gains/amplifications or mutations [10]. For example, MYC expression is tightly regulated in normal cells, but becomes dysregulated in up to $70 \%$ of all human cancers [11]. The most important mechanisms underlying abnormal MYC protein expression include: (1) structural alterations (e.g., MYC translocation or amplification), (2) enhanced transcription (e.g., super-enhancer activation [12]; PVT1 promoter deletion [13]; and aberrant upstream signaling, particularly B-cell receptor and NF- $\mathrm{kB}$ pathways [14]), and (3) altered protein stability (e.g., MYC T58 mutations [15]; and direct phosphorylation by Aurora B Kinase [16]. Multiple studies have identified double expressor status to be an adverse prognostic factor for response to R-CHOP in DLBCL [3,17-19]. Concurrent double expressor status has even been associated with poorer outcomes in tumors harboring DH cytogenetics $[17,20]$. Further, cases with double expressor status have demonstrated distinctive clinical features such as older age and advanced stage [20,21], higher LDH level [22], higher Ki67 proliferation index [23], and higher international prognostic index [24]. The revised $2016 \mathrm{WHO}$ classification recommends cutoff values of $40 \%$ for MYC and 50\% for BCL2 expression as assessed by immunohistochemistry (IHC) [7]; however, actual cutoff values have varied widely among published studies.

Increasing recognition of the potential prognostic value of MYC and BCL2 co-expression prompted this systematic review and meta-analysis of the worldwide literature. The primary aim of this study was to establish the incidence of double expressor status in patients with de novo DLBCL using pooled estimates according to different IHC cutoff values. The secondary aim of this study was to identify the predictive value of double expressor status on treatment response through meta-analysis.

\section{Methods}

This systematic review and meta-analysis is organized according to the Preferred Reporting Items for Systematic Reviews and Meta-Analyses (PRISMA) statement [25]. 


\subsection{Search Strategy and Selection Criteria}

PubMed and Embase were searched for articles and abstracts published through 4 December 2019, using the following search terms: ((diffuse large B cell lymphoma) OR (DLBCL)) AND ((double hit) OR (double expressor) OR (dual expressor) OR (myc bcl2) OR (myc bcl-2)). The language was restricted to English.

The inclusion criteria were as follows: (1) patients with newly diagnosed or de novo DLBCL; and (2) detailed data sufficient to assess the proportion of MYC/BCL2 protein co-expression. The exclusion criteria were as follows: (1) conference abstracts, review articles, opinions, letters, comments, editorials, guidelines, case reports, systematic reviews; (2) studies conducted in animals; (3) studies including primary CNS lymphoma; (4) insufficient data for evaluating outcome; and (5) overlapping study populations and data. Studies with larger sample sizes were selected when overlapping with smaller studies. Manual searches (using Google Scholar) for articles describing the use of the DLBCL90 NanoString gene expression assay were conducted to assess the prevalence of the double-hit gene expression signature (DHITsig) and DH/TH lymphoma in germinal center B-cell-like (GCB)-type DLBCL.

\subsection{Data Extraction and Quality Assessment}

The following data were extracted using a standardized data form:

1. Study: authors, publication year, patient enrollment period, institution, country, design

2. Pathological data: cut-off values of MYC and BCL2 protein expression by IHC, proportion of positive tumor cells for each marker and double expressor status, IHC protocol details.

3. Patient: number of patients, age, gender, clinical setting, international prognostic index, Ann Arbor Stage, prevalence of elevated LDH, treatment arm, complete remission (CR) rate.

4. DHIT-sig: proportion of DHITsig-positive cases, proportion of DH/TH lymphoma, the numbers of true positives, true negatives, false positives, and false negatives of DHIT-sig for predicting DH/TH lymphoma.

The quality of included studies was assessed using the Newcastle-Ottawa scale for cohort and case-control studies [26,27]. The Newcastle-Ottawa scale consists of three domains (Selection, Comparability, and Outcome). A study can be awarded a maximum of one point for each item in the Selection and Outcome domains, and two points for each item in the Comparability domain. The total (sum) of all scores reflects the overall quality of a given study: $8-9$, very good; 6-7, good; 4-5, satisfactory; 0-3, unsatisfactory [26]. Data extraction and quality assessment were performed by two independent reviewers (J.H. and C.H.S.) and disagreements were settled by consensus.

\subsection{Data Synthesis and Analysis}

The primary outcome was the pooled proportion of double expressor status among de novo DLBCL tumors. The secondary outcomes were as follows: (1) the results of subgroup analysis for the studies according to cut-off values of MYC and BCL2 protein expression, (2) pooled proportions of MYC and BCL2 protein expression (separately), (3) pooled odds ratio (OR) for CR rate in those with and without MYC/BCL2 protein co-expression.

The pooled proportions of double expressor status as well as MYC and BCL2 protein expression (independently) were computed using the inverse variance method for calculating weights and by the DerSimonian-Laird method [28]. For the analysis of MYC and BCL2 protein expression, the pre-determined cut-off values from individual studies were used. The pooled OR with $95 \%$ confidence interval (CI) was calculated with double expressor status as the base category. Pooled estimates of sensitivity and specificity were calculated using a bivariate random effects model [29]. Study heterogeneity was evaluated using the inconsistency index $\left(\mathrm{I}^{2}\right)$ of Higgins et al. [30] with a cut-off of $50 \%$, and the $Q$ test with a $p$-value $<0.10$ used to indicate statistical heterogeneity. Data were meta-analytically pooled using a random effects model for more conservative assessment 
of the incidence of double expressor status and ORs of CR rate [28]. Publication bias was assessed using visual inspection of funnel plots and Eggers test with a value $<0.1$ used to indicate significant bias [31]. Meta-regression analyses were conducted according to the cut-off values of MYC and BCL2 protein expression, mean or median age of patients, overall study quality, and race. The median age value calculated from the included studies was used as a cut-off for heterogeneity exploration. Statistical analysis was conducted by one author (C.H.S.) with the "meta" and "mada" packages in R software version 3.6.1 (R Foundation for Statistical Computing).

\section{Results}

\subsection{Literature Search and Quality Assessment}

A total of 1691 articles were initially retrieved by our systematic search. Thirty-four duplicate studies were removed and 1556 articles were further excluded after screening titles and abstracts (Figure 1). After reviewing the full-text of 101 potentially eligible articles, 57 studies were removed due to following reasons: 14 studies included partially overlapping patient cohorts, 17 studies were outside the field of interest, 10 studies reported data on primary CNS lymphoma, and 18 studies lacked necessary outcome data. One additional study was removed after quality assessment. This study, by Wang et al., selected patients based on pre-determined outcomes [32]. In total, 41 studies encompassing 7054 patients were retained for further analysis of double expressor status [3,19-21,33-69].



Figure 1. Flow diagram showing study selection process for systematic review.

Since the Newcastle-Ottawa scale was designed for cohort and case-control studies, we considered the selection domains for six secondary analysis studies of previous clinical trials to be of good quality (i.e., four points awarded). Overall, 28 studies received a "very good" quality rating and 13 studies a "good" quality rating (Table S1).

Three additional articles were retrieved due on their inclusion of DLBCL90 NanoString assay data [70-72]. All three of these studies received "very good" quality ratings (total scores of nine), although none provided sufficient details regarding the adequacy of follow up (outcome domain).

\subsection{Characteristics of the Included Studies}

The study and patient characteristics of the 41 included studies are listed in Tables 1 and 2, and Table S2. Detailed antibody information was available in all but one study (40/41, $98 \%$ ) (Table S3). For the majority of studies $(27 / 41,66 \%)$, additional information regarding the staining platform or other technical conditions was also included. IHC interpretation was performed by hematopathologists or other pathologists nearly three-quarters of the time $(30 / 41,73.2 \%)$. 
Table 1. Study characteristics.

\begin{tabular}{|c|c|c|c|c|c|c|c|}
\hline \multirow[t]{2}{*}{ First Author } & \multirow[t]{2}{*}{ Publication Year } & \multirow{2}{*}{ Patient Enrollment Period } & \multirow[t]{2}{*}{ Institution } & \multirow[t]{2}{*}{ Country } & \multirow[t]{2}{*}{ Design } & \multicolumn{2}{|c|}{ IHC Cut-Off Values for Protein Expression } \\
\hline & & & & & & MYC & BCL2 \\
\hline Abdulla M & 2016 & 2002-2012 & $\begin{array}{l}\text { Uppsala University and } \\
\text { University Hospital }\end{array}$ & Sweden & $\mathrm{R}$ & $40 \%$ & $70 \%$ \\
\hline Birceanu Corobea A & 2018 & NA & Coltea Clinical Hospital & Romania & NA & $40 \%$ & $50 \%$ \\
\hline Clark Schneider KM & 2016 & NA & Cleveland Clinic & USA & NA & $40 \%$ & $50 \%$ \\
\hline Fogliatto L & 2019 & 2011-2016 & Hospital Santa Rita & Brazil & $\mathrm{R}$ & $40 \%$ & $40 \%$ \\
\hline Green TM & 2012 & 2001-2008 & Various centers & Denmark & $\mathrm{R}$ & $40 \%$ & $70 \%$ \\
\hline Hori Y & 2019 & 1999-2018 & $\begin{array}{c}\text { Kyushu University Hospital and } \\
\text { its affiliated hospitals }\end{array}$ & Japan & $\mathrm{R}$ & $40 \%$ & $50 \%$ \\
\hline Jesionek-Kupnicka D & 2019 & 2017-2018 & Medical University of Lodz & Poland & $\mathrm{R}$ & $40 \%$ & $50 \%$ \\
\hline Johnson NA & 2012 & NA & Various centers & Various countries & NA & $40 \%$ & $50 \%$ \\
\hline Jovanovic MP & 2015 & $2001-2005$ & Clinical Center of Serbia & Serbia & $\mathrm{R}$ & $30 \%$ & $50 \%$ \\
\hline Klanova M & 2019 & 2011-2014 & Various centers & Various countries & $\begin{array}{l}\text { Secondary analysis } \\
\text { (Clinical trial, Phase 3) }\end{array}$ & $40 \%$ & $50 \%$ \\
\hline Li L & 2018 & 2012-2015 & $\begin{array}{l}\text { Tianjin MedicalUniversity Cancer } \\
\text { Institute and Hospital }\end{array}$ & China & $\mathrm{R}$ & $40 \%$ & $50 \%$ \\
\hline Liu $Y$ & 2017 & $2006-2016$ & $\begin{array}{c}\text { Xi Jing Hospital and Tang Du } \\
\text { Hospital in Xi'an }\end{array}$ & China & $\mathrm{R}$ & $40 \%$ & $50 \%$ \\
\hline Lu TX & 2015 & 2006-2014 & $\begin{array}{l}\text { First Affiliated Hospital of } \\
\text { Nanjing Medical University }\end{array}$ & China & $\mathrm{R}$ & $40 \%$ & $50 \%$ \\
\hline Ma Z & 2019 & 2015-2017 & $\begin{array}{l}\text { First Affiliated Hospital of } \\
\text { Xinjiang Medical University }\end{array}$ & China & $\mathrm{R}$ & $50 \%$ & $70 \%$ \\
\hline Mohammed AA & 2019 & 2011-2015 & Zagazig University & Egypt & $\mathrm{R}$ & $40 \%$ & $50 \%$ \\
\hline Molina TJ & 2014 & 2003-2008 & Various centers & $\begin{array}{l}\text { France, Belgium, and } \\
\text { Switzerland }\end{array}$ & $\begin{array}{l}\text { Secondary analysis } \\
\text { (Clinical trial, Phase 3) }\end{array}$ & $40 \%$ & $70 \%$ \\
\hline $\mathrm{NaHY}$ & 2019 & 1996-2016 & $\begin{array}{c}\text { Seoul National University } \\
\text { Hospital, Seoul National } \\
\text { University Bundang Hospital and } \\
\text { Seoul National University } \\
\text { Boramae Hospital }\end{array}$ & Korea & 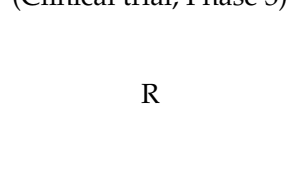 & $40 \%$ & $50 \%$ \\
\hline Pedersen MO & 2017 & 2004-2008 & $\begin{array}{c}\text { NA } \\
\text { Oulu and Kuopio University }\end{array}$ & Denmark & $\mathrm{R}$ & $40 \%$ & $70 \%$ \\
\hline Peroja P & 2018 & 2003-2011 & $\begin{array}{l}\text { Hospitals and Central Hospital of } \\
\text { Central Finland }\end{array}$ & Finland & $\mathrm{R}$ & $40 \%$ & $70 \%$ \\
\hline Perry AM & 2014 & NA & $\begin{array}{l}\text { University ofNebraska } \\
\text { Medical Center }\end{array}$ & USA & NA & $50 \%$ & $30 \%$ \\
\hline
\end{tabular}


Table 1. Cont.

\begin{tabular}{|c|c|c|c|c|c|c|c|}
\hline \multirow[t]{2}{*}{ First Author } & \multirow[t]{2}{*}{ Publication Year } & \multirow{2}{*}{ Patient Enrollment Period } & \multirow[t]{2}{*}{ Institution } & \multirow[t]{2}{*}{ Country } & \multirow[t]{2}{*}{ Design } & \multicolumn{2}{|c|}{ IHC Cut-Off Values for Protein Expression } \\
\hline & & & & & & MYC & BCL2 \\
\hline Petrella T & 2017 & NA & Various centers & $\begin{array}{l}\text { France, Belgium, } \\
\text { Switzerland, and } \\
\text { Portugal }\end{array}$ & $\begin{array}{l}\text { Secondary analysis } \\
\text { (Clinical trial, Phase 3) }\end{array}$ & $40 \%$ & $70 \%$ \\
\hline Phang KC & 2019 & $2004-2010$ & UKM Medical Centre & Malaysia & $\mathrm{R}$ & $40 \%$ & $70 \%$ \\
\hline Rajnai H & 2014 & NA & $\begin{array}{l}\text { Semmelweis University and the } \\
\text { Leiden University Medical Center }\end{array}$ & Hungary, Netherlands & NA & $30 \%$ & $30 \%$ \\
\hline Scott DW & 2015 & NA & British Columbia Cancer Agency & Canada & NA & $40 \%$ & $50 \%$ \\
\hline Sha $C$ & 2019 & NA & NA & Swiss and England & $\begin{array}{l}\text { Secondary analysis } \\
\text { (Clinical trial, Phase 3) }\end{array}$ & $40 \%$ & $50 \%$ \\
\hline Staiger AM & 2017 & NA & Various centers & $\begin{array}{l}\text { Germany and } \\
\text { Switzerland }\end{array}$ & $\begin{array}{l}\text { Secondary analysis } \\
\text { (Clinical trial, Phase 3) }\end{array}$ & $40 \%$ & $50 \%$ \\
\hline Suresh B & 2019 & 2016-2017 & Kidwai Cancer Institute & India & $\mathrm{P}$ & NA & NA \\
\hline Takahashi H & 2016 & $2001-2013$ & $\begin{array}{c}\text { Nihon University School of } \\
\text { Medicine }\end{array}$ & Japan & $\mathrm{R}$ & $40 \%$ & $50 \%$ \\
\hline Teoh CS & 2018 & 2012-2015 & Hospital Pulau Pinang & Malaysia & $\mathrm{R}$ & $40 \%$ & $30 \%$ \\
\hline Tessier-Cloutier B & 2019 & NA & $\begin{array}{c}\text { NA } \\
\text { Hospital Ampang, Queen }\end{array}$ & Sweden, Canada, USA & NA & $40 \%$ & $50 \%$ \\
\hline Ting CY & 2019 & 2012-2013 & $\begin{array}{c}\text { Elizabeth Hospital, Hospital Pulau } \\
\text { Pinang and Sarawak General } \\
\text { Hospital }\end{array}$ & Malaysia & $\mathrm{R}$ & $40 \%$ & $50 \%$ \\
\hline Xia B & 2015 & 2005-2010 & $\begin{array}{l}\text { Tianjin Medical University Cancer } \\
\text { Institute and Hospital } \\
\text { Los Angeles County and }\end{array}$ & China & NA & $30 \%$ & $30 \%$ \\
\hline Xie $Y$ & 2014 & 2002-2012 & $\begin{array}{c}\text { University of Southern California } \\
\text { Medical Center }\end{array}$ & USA & $\mathrm{R}$ & $40 \%$ & $70 \%$ \\
\hline Xu PP & 2017 & 2002-2012 & Shanghai Rui Jin Hospital & China & $\mathrm{R}$ & $40 \%$ & $70 \%$ \\
\hline Yan LX & 2014 & 2000-2012 & Guangdong General Hospital & China & NA & $40 \%$ & $70 \%$ \\
\hline Ye Q & 2016 & 1998-2010 & Various centers & Various countries & NA & $70 \%$ & $70 \%$ \\
\hline Zhang Y & 2018 & 2015-2016 & Weifang People's Hospital & China & $\mathrm{R}$ & $40 \%$ & $50 \%$ \\
\hline
\end{tabular}

$\mathrm{R}=$ retrospective; $\mathrm{P}$ = prospective; $\mathrm{IHC}=$ immunohistochemistry; $\mathrm{NA}=$ not available. 
Table 2. Patient characteristics.

\begin{tabular}{|c|c|c|c|c|}
\hline First Author & Patients $(N)$ & Age (Range) & Male to Female Ratio & Clinical Setting \\
\hline Abdulla M & 188 & $64(26-85)$ & $1.4: 1$ & De novo DLBCL \\
\hline Barraclough A & 175 & $62(19-89)$ & $1: 1$ & PET-CT defined stage I/II DLBCL \\
\hline Birceanu Corobea A & 80 & $57.26(19-87)$ & $1.1: 1$ & DLBCL \\
\hline Clark Schneider KM & 69 & $62 * *$ & $1: 1$ & De novo DLBCL \\
\hline Fogliatto L & 83 & $64(15-92)$ & $1: 1.4$ & DLBCL \\
\hline Friedberg JW & 84 & $64(29-85)$ & $1: 1.2$ & $\begin{array}{c}\text { Newly diagnosed advanced stage } \\
\text { DLBCL }\end{array}$ \\
\hline Green TM & 193 & $64(16-91)$ & $1.4: 1$ & De novo DLBCL \\
\hline Hori Y & 23 & $65(38-84)$ & $1.3: 1$ & Primary colorectal DLBCL \\
\hline Jesionek-Kupnicka D & 217 & 68.73 & $1: 1.2$ & DLBCL \\
\hline Johnson NA & $167^{\mathrm{a}}$ & $62(17-92)$ & NA & De novo DLBCL \\
\hline Jovanovic MP & 103 & $56(17-87)$ & 1:1.1 & De novo DLBCL \\
\hline Klanova M & $688^{b}$ & NA & NA & DLBCL in the phase 3 GOYA study \\
\hline Li L & 212 & $58.5(21-86)$ & 1.2:1 & Newly diagnosed DLBCL \\
\hline $\mathrm{Li} \mathrm{M}$ & 35 & $62(23-89)$ & $2: 1$ & Anaplastic DLBCL \\
\hline Liu Y & 100 & NA & 1.1:1 & Primary gastrointestinal DLBCL \\
\hline Lu TX & 246 & NA & NA & De novo DLBCL \\
\hline Ma Z & 98 & $55(8-76)$ & 1.3:1 & De novo DLBCL \\
\hline Mohammed AA & 90 & $58(25-90)$ & $1.2: 1$ & De novo DLBCL \\
\hline Molina TJ & 379 & NA & NA & De novo DLBCL \\
\hline Na HY & 195 & NA & $1.3: 1$ & De novo DLBCL \\
\hline Pedersen MO & 103 & NA (18-60) & 1.3:1 & De novo high-risk DLBCL \\
\hline Peroja P & 155 & NA & $1.2: 1$ & De novo DLBCL \\
\hline Perry AM & $106^{c}$ & $61(19-89)$ & $1.2: 1$ & De novo DLBCL \\
\hline Petrella T & 285 & $70(59-80)$ & 2.2:1 & Untreated elderly patients with DLBCL \\
\hline Phang KC & 141 & NA & NA & DLBCL \\
\hline Rajnai $\mathrm{H}$ & 41 & $50(11-78)$ & $2.4: 1$ & Primary bone DLBCL \\
\hline Scott DW & 344 & $64(16-92)$ & $1.6: 1$ & De novo DLBCL \\
\hline Sha C & $355^{d}$ & NA & NA & Newly diagnosed DLBCL \\
\hline Staiger AM & 414 & NA & $\begin{array}{l}\text { 1:1 (RICOVER-60 Trial), 1.4:1 } \\
\text { (R-MegaCHOEP Trial) }\end{array}$ & Untreated DLBCL \\
\hline Suresh B & 21 & $46(27-69)$ & $2.5: 1$ & Primary gastrointestinal DLBCL \\
\hline Takahashi H & 40 & $53(19-68)$ & $1: 1.3$ & $\begin{array}{c}\text { De novo DLBCL with } \\
\text { high/high-intermediate risk by aaIPI }\end{array}$ \\
\hline Teoh CS & 104 & NA & $1: 1$ & DLBCL \\
\hline Tessier-Cloutier B & 20 & $58(48-66)$ & $9: 1$ & SLE diagnosed with DLBCL \\
\hline Ting CY & 120 & $54.1(14.6)^{* *}$ & 1.1:1 & De novo DLBCL \\
\hline Wang XJ & 201 & $64(18-92)$ & 1.9:1 & De novo DLBCL \\
\hline Xia B & 60 & $57(23-79)$ & $1.1: 1$ & Primary gastrointestinal DLBCL \\
\hline Xie Y & 85 & $54(20-89)$ & $1.5: 1$ & De novo DLBCL \\
\hline $\mathrm{Xu} \mathrm{PP}$ & $470^{\mathrm{e}}$ & NA & NA & De novo DLBCL \\
\hline Yan LX & 336 & $57(7-87)$ & $1.4: 1$ & De novo DLBCL \\
\hline Ye Q & 898 & $64(16-95)$ & NA & De novo DLBCL \\
\hline Zhang Y & 42 & $58.9(43-80)$ & $1.6: 1$ & Newly diagnosed DLBCL \\
\hline
\end{tabular}

${ }^{a}$ Training cohort in the study; ${ }^{\mathrm{b}}$ Among 1418 patients, MYC/BCL2 protein expression was available from 688 patients; ${ }^{\mathrm{c}}$ Training cohort in the study; ${ }^{\mathrm{d}}$ Among 928 patients, a subset of 355 patients was investigated for MYC/BCL2 protein expression; ${ }^{\mathrm{e}}$ Among 680 patients, MYC/BCL2 protein expression was available from 470 patients; ${ }^{* *}$ Age is presented as mean ( \pm standard deviation). Other age data are presented as median. $\mathrm{NA}=$ not available.

In brief, the study design was prospective in one study [59], retrospective in $22[3,32,33,36,38-40,42,44-47,49-51,54,60,61,63,66,67,69]$, secondary analysis of primary clinical trials in six [37,41,48,53,57,58], and not-explained in 12 [19-21,34,35,43,52,55,56,62,65,68]. The number of patients per study ranged from 20 to 688 , with median ages of $46-70$ years. Regarding cutoff values for MYC and BCL2 protein expression, 21 studies used $>40 \%$ and $>50 \%[20,33-35,38,39,41-45,47,49,56-58,60,62-64,69], 10$ studies used $>40 \%$ and $>70 \%[3,19,48$, $50,51,53,54,66-68]$, and two studies used $>30 \%$ and $>30 \%[55,65]$. Six studies used other various criteria to define MYC and BCL2 protein expression [21,36,40,46,52,61]. Among the included studies, five evaluated only extra-nodal DLBCL (gastrointestinal, colorectal, and primary bone DLBCL) $[38,44,55,59,65]$. Sixteen studies were performed in Asian countries [38,42-46,49,54,59-61,63,65,67-69], 12 in Europe [3,19,34,39,40,48,50,51,53,55,57,58], and six in North America $[35,37,52,56,64,66]$. The proportions of MYC and BCL2 protein 
expression were reported in 29 studies [19-21,37-40,42-55,57,58,62,64-66,68,69] and 30 studies [19-21,33,37-40,42-55,57,58,62,64-66,68,69], respectively.

\subsection{Meta-Analytic Pooled Prevalence of Double Expressor Status and MYC and BCL2 Protein Expression}

The pooled outcomes for the 41 included studies are summarized in Table 3. The proportion of DLBCL tumors attaining double expressor status varied between $6 \%$ and $50 \%$, with a pooled proportion of $23 \%(95 \% \mathrm{CI}, 20-26 \%)$, with significant heterogeneity between studies $\left(\mathrm{I}^{2}=90 \%, p<0.001\right)$ (Figure 2). The funnel plot (Figure S1) and Egger's test $(p<0.001)$ revealed publication bias. After using the trim-and-fill method, the publicationbias-adjusted pooled proportion was 31\% (95\% CI, 27-36\%).

Table 3. Summary of the meta-analytic pooled prevalence for various outcomes among the included studies.

\begin{tabular}{|c|c|c|c|c|c|c|c|}
\hline \multirow[b]{2}{*}{ Outcome } & \multirow[b]{2}{*}{$\begin{array}{l}\text { No. of } \\
\text { Studies }\end{array}$} & \multicolumn{3}{|c|}{ Summary Estimate } & \multirow[b]{2}{*}{$\begin{array}{l}p \text { Value for } \\
\text { Publication } \\
\text { Bias }^{c}\end{array}$} & \multicolumn{2}{|c|}{ Trim-and-Fill Estimate } \\
\hline & & $\begin{array}{c}\text { Pooled } \\
\text { Proportion (\%) } \\
(95 \% \text { CI) }\end{array}$ & $\begin{array}{c}p \text { Value for } \\
\text { Hetero-Geneity }^{a}\end{array}$ & $I^{2}(\%)^{b}$ & & $\begin{array}{l}\text { No. of } \\
\text { Missing } \\
\text { Studies }\end{array}$ & $\begin{array}{c}\text { Adjusted } \\
\text { Pooled } \\
\text { Proportion } \\
(95 \% \mathrm{CI})\end{array}$ \\
\hline $\begin{array}{l}\text { Double expressor } \\
(\mathrm{MYC}+, \mathrm{BCL} 2+)\end{array}$ & 41 & $23(20-26)$ & $<0.001$ & 90 & $<0.001$ & 16 & $31(27-36)$ \\
\hline MYC protein expression & 29 & $34(30-39)$ & $<0.001$ & 90 & 0.421 & & \\
\hline BCL2 protein expression & 30 & $58(53-62)$ & $<0.001$ & 90 & 0.585 & & \\
\hline $\begin{array}{c}\text { Double expressor } \\
(\mathrm{MYC}>40 \% \text {, BCL2 > 50\%) }\end{array}$ & 21 & $20(16-26)$ & $<0.001$ & 92 & $<0.001$ & 9 & $32(26-39)$ \\
\hline $\begin{array}{c}\text { Double expressor } \\
(\mathrm{MYC}>40 \% \text {, BCL2 > 70\%) }\end{array}$ & 10 & $27(23-32)$ & $<0.001$ & 79 & 0.07 & 3 & $30(25-35)$ \\
\hline $\begin{array}{l}\text { Double expressor in } \\
\text { Asian countries }\end{array}$ & 16 & $23(17-28)$ & $<0.001$ & 87 & 0.05 & 5 & $30(23-37)$ \\
\hline Double expressor in Europe & 12 & $21(17-27)$ & $<0.001$ & 87 & 0.006 & 5 & $29(23-37)$ \\
\hline $\begin{array}{c}\text { Double expressor in } \\
\text { North America }\end{array}$ & 6 & $29(20-39)$ & $<0.001$ & 88 & $\mathrm{NA}^{\mathrm{d}}$ & & \\
\hline $\begin{array}{l}\text { Double expressor in studies } \\
\text { with median age } \geq 60.3\end{array}$ & 16 & $25(19-31)$ & $<0.001$ & 93 & 0.16 & & \\
\hline $\begin{array}{l}\text { Double expressor in studies } \\
\text { with median age }<60.3\end{array}$ & 14 & $20(16-24)$ & $<0.001$ & 63 & 0.03 & 6 & $25(21-30)$ \\
\hline
\end{tabular}

${ }^{\mathrm{a}} p$ value was determined by the $\mathrm{Q}$ test with $p<0.05$ representing substantial heterogeneity. ${ }^{\mathrm{b}}$ Inconsistency index $>50 \%$ indicates substantial heterogeneity. ${ }^{c} p$ values were calculated by Egger's test with $<0.1$ representing significant publication bias. ${ }^{\mathrm{d}}$ A $p$ value is not available due to the small number of included studies $(n<10)$.

The pooled proportions of MYC and BCL2 protein expression were $34 \%$ (95\% CI, $30-39 \%)$ and $58 \%(95 \%$ CI, 53-62\%), respectively, with significant heterogeneity between studies (all $\left.\mathrm{I}^{2}>50 \%, p<0.001\right)$. Egger's test showed no publication bias in analyses of MYC or BCL2 protein expression (all $p>0.1$ ).

\subsection{Heterogeneity Exploration}

Subgroup analysis was performed for the different combinations of cutoff values for MYC and BCL2 protein expression $(>40 \%$ and $>50 \%,>40 \%$ and $>70 \%,>30 \%$ and $>30 \%$, and not-available, respectively), race, mean, or median age of included patients, and overall study quality (Table 3). The pooled proportion of double expressor status from studies using cut-off values of $>40 \%$ and $>50 \%$ was $20 \%(95 \% \mathrm{CI}, 16-26 \%)$, with significant heterogeneity between studies $\left(\mathrm{I}^{2}=92 \%, p<0.001\right)$ (Figure 2). The funnel plot (Supplementary Materials Figure S1) and Egger's test $(p<0.001)$ showed publication bias, and the publication-biasadjusted pooled proportion of double expressor status from studies using cutoff values of $>40 \%$ and $>50 \%$ was $32 \%$ (95\% CI, $26-39 \%$ ). The pooled proportion of double expressor status from studies using cutoff values of $>40 \%$ and $>70 \%$ was $27 \%(95 \% \mathrm{CI}, 23-32 \%)$, with significant heterogeneity between studies $\left(\mathrm{I}^{2}=79 \%, p<0.001\right)$ (Figure 2$)$. The funnel plot (Figure S1) and Egger's test $(p=0.07)$ showed publication bias, and the publication-biasadjusted pooled proportion of double expressor status from studies using cutoff values of $>40 \%$ and $>70 \%$ was $30 \%$ (95\% CI, $25-35 \%$ ). 


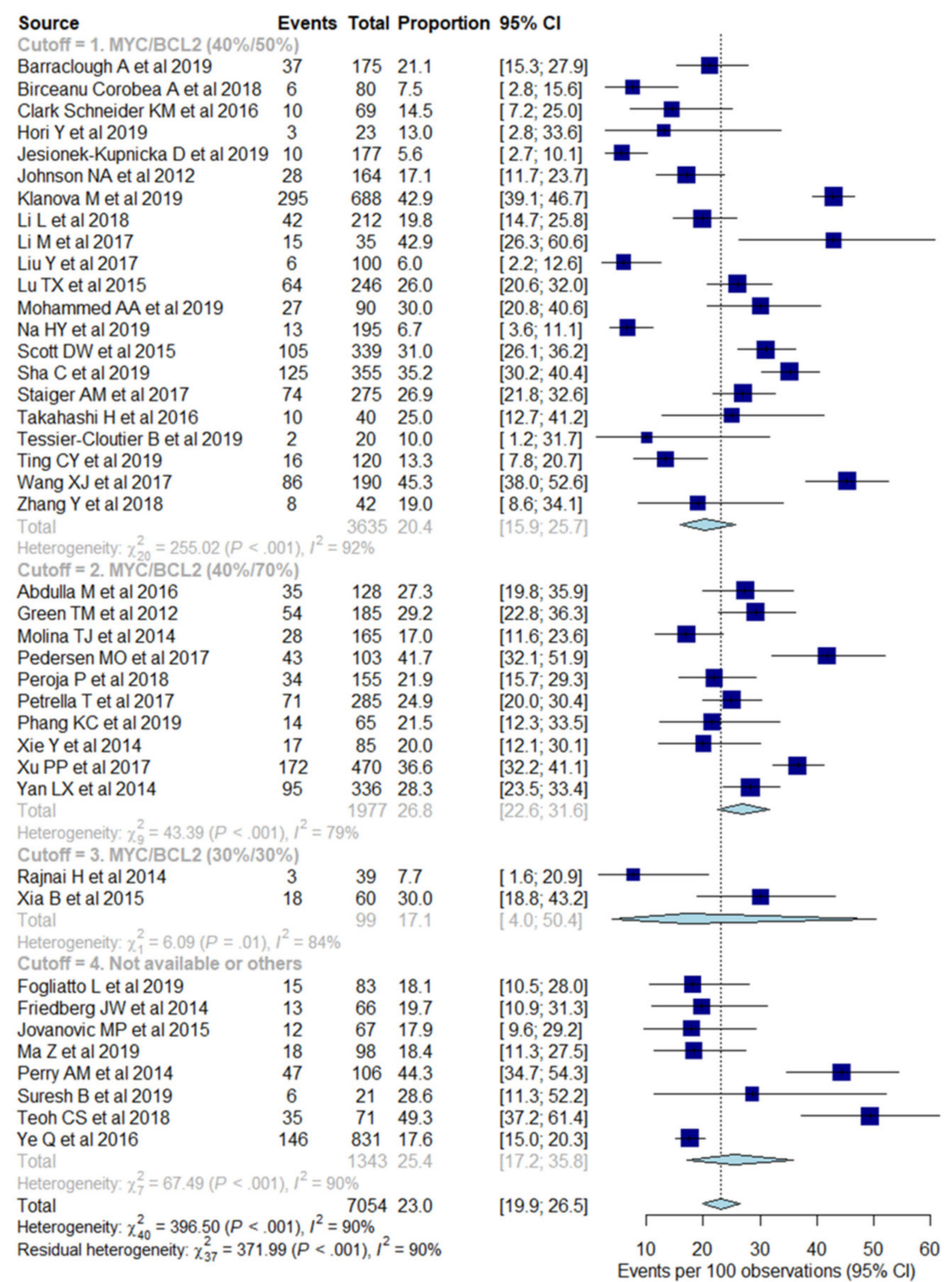

Figure 2. Forest plots show pooled proportion of double protein expression of MYC and BCL2, stratified to different cutoff values by immunohistochemical staining. The events represent double expressor status. The blue box represents the point estimate and its area represents the weight given to the study and a horizontal line indicates the $95 \%$ confidence interval. The diamond represents the combined results and the length of the diamond indicates the confidence interval of the pooled results. At the bottom of the plot, the overall pooled proportion is represented by the dashed vertical line and the diamond.

The pooled proportion of double expressor status from studies performed in Asian countries was 23\% (95\% CI, 17-28\%), in Europe was 21\% (95\% CI, 17-27\%), and in North America was 29\% (95\% CI, 20-39\%), with significant heterogeneity between studies $\left(\mathrm{I}^{2}>50 \%\right)$. The pooled proportion of double expressor status in studies of very good quality was $24 \%$ (95\% CI, 20-28\%) and in studies of good quality was $21 \%$ (95\% CI, 16-28\%), with significant heterogeneity between studies $\left(\mathrm{I}^{2}>50 \%\right)$. The pooled proportion of double expressor status in studies with mean or median age $\geq 60.3$ was $25 \%$ (95\% CI, 19-31\%) and in studies with mean or median age <60.3 was 20\% (95\% CI, 16-24\%), with significant heterogeneity between studies $\left(\mathrm{I}^{2}>50 \%\right)$. Upon meta-regression analyses, all covariates (cut-off values for MYC and BCL2 protein expression, race, mean or median age of in- 
cluded patients, and overall study quality) were shown not to be significant factors of heterogeneity with $p$-values of $0.28,0.56,0.20$, and 0.49 , respectively.

\subsection{Odds Ratio for Complete Remission Rate in Those with and without MYC/BCL2 Protein Co-Expression}

$\mathrm{CR}$ rates from subjects with and without MYC/BCL2 protein co-expression were available from eight studies $[3,21,47,60,61,63,65,67]$. Cases without double expressor status had a significantly higher probability for achievement of CR (combined OR, 2.69; 95\% CI, 1.55-4.67) than cases with double expressor status with significant heterogeneity between studies $\left(\mathrm{I}^{2}=68 \%, p<0.01\right)$ (Figure 3 ). Publication bias could not be assessed due to the small number of included studies.

\begin{tabular}{|c|c|c|c|c|c|c|}
\hline Source & $\begin{array}{l}\text { Experir } \\
\text { Events }\end{array}$ & $\begin{array}{l}\text { mental } \\
\text { Total }\end{array}$ & $\begin{array}{l}\text { Control } \\
\text { Events }\end{array}$ & Total & I OR & $95 \% \mathrm{Cl}$ \\
\hline Green TM et al 2012 & 117 & 131 & 38 & 54 & 3.52 & {$[1.57 ; 7.87]$} \\
\hline Xia B et al 2015 & 39 & 42 & 9 & 18 & 13.00 & {$[2.92 ; 57.93]$} \\
\hline Takahashi H et al 2016 & 25 & 30 & 8 & 10 & 1.25 & {$[0.20 ; 7.74]$} \\
\hline Ye Q et al 2016 & 501 & 636 & 79 & 164 & 3.99 & {$[2.78 ; 5.73]$} \\
\hline Xu PP et al 2017 & 239 & 298 & 123 & 170 & 1.55 & {$[1.00 ; 2.40]$} \\
\hline Teoh CS et al 2018 & 22 & 36 & 20 & 35 & 1.18 & {$[0.46 ; 3.04]$} \\
\hline Mohammed AA et al 2019 & 20 & 63 & 0 & 27 & 25.92 & {$[1.51 ; 446.19]$} \\
\hline Ting CY et al 2019 & 24 & 46 & 5 & 12 & 1.53 & {$[0.42 ; 5.52]$} \\
\hline $\begin{array}{l}\text { Total } \\
\text { Heterogeneity: } \chi_{7}^{2}=22.13(\end{array}$ & 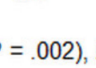 & $\begin{array}{r}1282 \\
t^{2}=68\end{array}$ & & 490 & 2.69 & {$[1.55 ; 4.67]$} \\
\hline
\end{tabular}

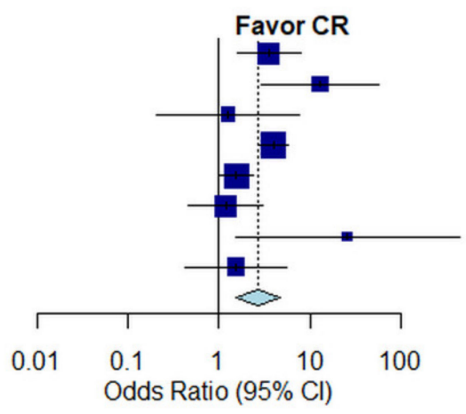

Figure 3. Forest plot shows the pooled odds ratio of complete remission in patients, stratified by double expressor status. The events represent complete remission. The blue box represents the point estimate and its area represents the weight given to the study. Horizontal line indicates the $95 \%$ confidence interval. At the bottom of the plot, the overall pooled odds ratio is represented by the dashed vertical line and the diamond. The solid vertical line indicates no effect.

\subsection{Evaluation of the Double-Hit Gene Expression Signature in De Novo DLBCL}

Study details and patient characteristics are provided in Table S4. Based on a limited number of available studies $(n=3)$, the pooled prevalence of DHITsig was $25 \%$ (95\% CI, 17.6-35.1; $\mathrm{I}^{2}=59.8 \%$ ) among GCB-type DLBCL. The pooled sensitivity of DHITsig for detecting DH/TH lymphoma was $83.5 \%\left(95 \% \mathrm{CI}, 66.6-92.8 ; \mathrm{I}^{2}=59.8 \%\right)$. The area under the hierarchical summary receiver operating characteristic curve was 0.901 . The pooled prevalence of DH/TH lymphoma among DHITsig-positive cases was 48.3\% (95\% CI, $\left.36.9-59.8 ; \mathrm{I}^{2}=9.7 \%\right)$. The pooled prevalence of double expressor status among DHITsigpositive cases was $53.6 \%\left(95 \% \mathrm{CI}, 41.6-65.2 ; \mathrm{I}^{2}=33.0 \%\right)$.

\section{Discussion}

In this systematic review and meta-analysis, we established the incidence of MYC/BCL2 co-expression in all de novo DLBCL studies published to date and calculated pooled estimates of double expressor status according to different IHC cutoff values. Our analysis of 41 studies meeting selection criteria revealed that approximately $23 \%$ of de novo DLBCL tumors express both MYC and BCL2 proteins. Variably utilized cutoff values for MYC and BCL2 protein expression, mean or median age of included patients, race and overall study quality did not significantly influence the proportion of tumors attaining double expressor status. Pooled estimates confirmed a significantly higher probability of complete remission (OR, 2.69; 95\% CI, 1.55-4.67) in cases without double expressor status. This comprehensive review of both the Western and Eastern literature provides a summary of worldwide data relating to double expressor DLBCL and its influence on therapeutic response.

Unlike DH/TH lymphoma, double expressor lymphoma is not regarded as a separate diagnostic entity in the current WHO blue book. Instead, assessment of double expressor status is best viewed as a valuable complement to routine $\mathrm{DH} / \mathrm{TH}$ fluorescence in situ hybridization (FISH) testing that can help to identify potentially aggressive tumors that are missed by conventional cytogenetic techniques. Indeed, double expressor DLBCL has 
a much higher reported prevalence of $20-30 \%$ [73] compared to the $6-14 \%$ prevalence of DH/TH DLBCL [2], and this meta-analysis confirms a pooled proportion of double expressor status of $23 \%$ with a publication-bias-adjusted estimate of $31 \%$. Another key feature of double expressor status is that the laboratory infrastructure and immunohistochemical reagents required to perform this testing are widely available due to the important diagnostic roles of both MYC and BCL2 in lymphoma pathology workups. By comparison, FISH analysis is far more costly, time-consuming and requires extra expertise and may therefore not always be available outside of referral laboratories and academic medical centers. Restricting FISH testing to the subset of GCB-type DLBCL with MYC and BCL2 co-expression has been proposed as a cost-effective approach for identifying high-risk patients [14]; however, this strategy would fail to identify roughly one-third of all DH/TH lymphomas [74]. Even when a selective approach to FISH testing is employed, double expressor status should never be viewed as a functional equivalent or alternative to the former. Many double expressor lymphomas do not harbor DH/TH cytogenetics, and the opposite is not always true either. For example, the MYC N11S variant, encoded by a common germline SNP, has been shown to hamper the immunohistochemical detection of MYC [9], and somatic mutations within the BCL2 gene are a known cause of false negative IHC results [75].

Beyond cell-of-origin, several recent studies have supported the use of gene expression profiling for the prediction of outcome in DLBCL. For example, Sha et al. described a "molecular high-grade" gene expression signature with distinct molecular features and poor outcomes irrespective of DH status [57]. Similar work by Ennishi et al. showed that a "double-hit gene expression signature" (DHITsig; captured by the DLBCL90 NanoString assay) can be used to identify cases of GCB-type DLBCL that share the same aggressive underlying biology exhibited by most GCB-type DLBCL tumors with MYC and BCL2 rearrangements [70]. Based on their data, nearly one-third of GCB-type DLBCL tumors express DHITsig, but only half of those have DH/TH cytogenetics by breakapart FISH or coexpress both MYC and BCL2 proteins [70]. Hilton et al. subsequently described a collection of DHITsig-positive tumors lacking DH/TH cytogenetics by breakapart FISH, but in which cryptic MYC or BCL2 rearrangements were detectable by whole-genome sequencing, thus making them true high-grade B-cell lymphomas with MYC and BCL2 rearrangements. Importantly, all of those cases were double protein expressors, highlighting the ability of MYC/BCL2 IHC to catch a few of the aggressive GCB-type DLBCL tumors that are falsely negative by breakapart FISH [76]. Collectively, the studies referenced above indicate that gene expression profiling can identify additional high-risk DLBCL tumors that are missed by FISH and IHC. Unfortunately, gene expression profiling is currently beyond the capabilities of most clinical laboratories and was not used by the vast majority of studies included in this work. In fact, we were only able to identify three published articles reporting the use of the DLBCL90 NanoString assay in DLBCL. Our preliminary assessment of these studies shows consistency across cohorts in regards to the overlap of DHITsig and DH/TH lymphoma. Future meta-analysis research will be needed to understand the broader impacts of novel gene expression signatures once clinical technologies have sufficiently advanced.

The WHO-recommended cutoff values of $>40 \%$ and $>50 \%$ were the most commonly used thresholds for defining MYC and BCL2 protein expression, respectively, within published studies meeting our inclusion criteria $(21 / 41,51 \%)$. This was followed by cutoff values of MYC $>40 \%$ and BCL2 $>70 \%(10 / 41,24 \%)$. However, these study-specific cutoff values did not significantly influence the proportions of reported double expressor status. Our results might suggest that several of the most commonly used cutoff values are similarly efficacious for defining double protein expression in patients with DLBCL. Alternatively, they would also appear to reflect the subjective nature of IHC assessment as well as other practical limitations discussed below.

Some studies have suggested that racial differences could account for response patterns and survival rates in patients with DLBCL $[77,78]$. For example, Chen et al. compared 
124 Chinese and 114 Western patients with DLBCL and their results suggested that BCL2 expression was more common in Chinese than Western cases [78]. Our meta-analytic results indicate that race is not significant influence on double expressor status.

Double expressor status has repeatedly been shown to be a negative predictor of survival $[2,7,73]$. Hu et al. reported significantly poorer survival in 893 de novo DLBCL patients with double expressor status treated with R-CHOP with a 5-year overall and progression free survival of $<30 \%$ [79]. Klanova et al. reported higher CNS relapse rates in patients with dual expressor status in the phase 3 GOYA study, but without statistical significance [41]. A previous meta-analysis revealed that double expressor status was related to poor overall survival in R-CHOP treated DLBCL [80]. In addition to previous studies, our meta-analytic results show that the absence of MYC and BCL2 co-expression is associated with a higher CR rate to R-CHOP (OR, 2.69; 95\% CI, 1.55-4.67), thereby reaffirming the clinical significance of this predictive biomarker.

There are several limitations to our work. Significant heterogeneity exists among the analyzed studies. Although we performed subgroup analyses to identify possible sources of heterogeneity, no significant variables were found and thus unidentified causes of heterogeneity are likely to exist. The accurate determination of MYC and BCL2 protein expression can be challenged by numerous obstacles including specimen limitations (e.g., tissue quantity and sample preservation) and technical factors (e.g., IHC reagents and conditions) [81,82], as well as by subjective evaluation. Additionally, the two included studies did not report on the IHC cut-off values for MYC and/or BCL2 protein expression $[37,59]$. All these might underlie a portion of the unexplained heterogeneity among studies. In the subgroup analysis according to the age of patients, individual patientlevel data was not available to perform an appropriate age analysis (i.e., comparing all of the young patients from all of the studies against all of the old patients from all of the studies), and this might explain the non-significant result. Six of eight $(75 \%)$ studies evaluated for $\mathrm{CR}$ were conducted in a retrospective design introducing the possibility that the pooled OR was overestimated. Various cutoff values were used between studies to define double expressor status. Although our results demonstrate that IHC cutoff values did not significantly influence the proportions of double expressor status, the different cutoff values might be a confounding factor for pooled estimates of $C R$ rates. Due to the absence of sufficient data on CR rate in studies that utilized treatments other than R-CHOP, we were unable to perform subgroup analyses to compare the effect of upfront treatment (R-CHOP versus other therapy) on CR rate. Finally, our analysis included only de novo or newly diagnosed DLBCL. To date, only a few studies have reported on MYC and BCL2 co-expression in relapsed or refractory DLBCL $[83,84]$, and therefore the prognostic value of double expressor status in this setting remains uncertain.

\section{Conclusions}

The pooled proportion of MYC/BCL2 double expressor status among patients with de novo DLBCL is $23 \%$ with an adjusted estimate of $31 \%$. Patients with DLBCL without double expressor status had a 2.7 times higher probability of complete remission compared to patients with double expressor DLBCL. Double expressor status appears to be a valuable predictive biomarker in DLBCL.

Supplementary Materials: The following are available online at https:/ /www.mdpi.com/article/10 .3390 / cancers13133369/s1, Figure S1: Funnel plots for pooled proportion of double protein expression of MYC and BCL2, Table S1: Newcastle-Ottawa Quality Assessment Scale of included studies in the synthesis of double expressor status, Table S2: Patient characteristics of included studies in the synthesis of double expressor status, Table S3: IHC protocols, Table S4: Study and patient characteristics from articles reporting DHITsig status in DLBCL.

Author Contributions: J.H. and C.H.S. are responsible for the collection of data. J.H. is responsible for drafting the manuscript. C.H.S., J.H., J.P.G., R.Y.H., K.X.C. and J.R. contributed to the planning and conception of this study. C.H.S. performed the literature search. J.H., J.W.C. and C.H.S. assessed the study quality. J.H. and C.H.S. extracted relevant contents. C.H.S., J.W.C., A.I.K., K.W.K., H.S.K., 
J.P.G. and R.Y.H. reviewed and edited the manuscript. C.H.S. performed statistical analysis. All authors have read and agreed to the published version of the manuscript.

Funding: This study was supported by the National Research Foundation of Korea (NRF) and Korea Health Industry Development Institute grants funded by the Korea government (No. 2021R1C1C101 4413, HI18C2383).

Institutional Review Board Statement: Not applicable.

Informed Consent Statement: Not applicable.

Data Availability Statement: The databases for the analyses of this study are available on request from the corresponding author.

Conflicts of Interest: The authors declare no conflict of interest.

\section{References}

1. Teras, L.R.; DeSantis, C.E.; Cerhan, J.R.; Morton, L.M.; Jemal, A.; Flowers, C.R. 2016 US lymphoid malignancy statistics by World Health Organization subtypes. CA Cancer J. Clin. 2016, 66, 443-459. [CrossRef]

2. Liu, Y.; Barta, S.K. Diffuse large B-cell lymphoma: 2019 update on diagnosis, risk stratification, and treatment. Am. J. Hematol. 2019, 94, 604-616. [CrossRef]

3. Green, T.M.; Young, K.H.; Visco, C.; Xu-Monette, Z.Y.; Orazi, A.; Go, R.S.; Nielsen, O.; Gadeberg, O.V.; Mourits-Andersen, T.; Frederiksen, M.; et al. Immunohistochemical double-hit score is a strong predictor of outcome in patients with diffuse large B-cell lymphoma treated with rituximab plus cyclophosphamide, doxorubicin, vincristine, and prednisone. J. Clin. Oncol. Off. J. Am. Soc. Clin. Oncol. 2012, 30, 3460-3467. [CrossRef]

4. Ziepert, M.; Hasenclever, D.; Kuhnt, E.; Glass, B.; Schmitz, N.; Pfreundschuh, M.; Loeffler, M. Standard International prognostic index remains a valid predictor of outcome for patients with aggressive CD20+ B-cell lymphoma in the rituximab era. J. Clin. Oncol. Off. J. Am. Soc. Clin. Oncol. 2010, 28, 2373-2380. [CrossRef]

5. Lenz, G.; Staudt, L.M. Aggressive lymphomas. N. Engl. J. Med. 2010, 362, 1417-1429. [CrossRef] [PubMed]

6. Tomita, N.; Tokunaka, M.; Nakamura, N.; Takeuchi, K.; Koike, J.; Motomura, S.; Miyamoto, K.; Kikuchi, A.; Hyo, R.; Yakushijin, Y.; et al. Clinicopathological features of lymphoma/leukemia patients carrying both BCL2 and MYC translocations. Haematologica 2009, 94, 935-943. [CrossRef] [PubMed]

7. Swerdlow, S.H.; Campo, E.; Pileri, S.A.; Harris, N.L.; Stein, H.; Siebert, R.; Advani, R.; Ghielmini, M.; Salles, G.A.; Zelenetz, A.D.; et al. The 2016 revision of the World Health Organization classification of lymphoid neoplasms. Blood 2016, 127, 2375-2390. [CrossRef] [PubMed]

8. Li, S.; Seegmiller, A.C.; Lin, P.; Wang, X.J.; Miranda, R.N.; Bhagavathi, S.; Medeiros, L.J. B-cell lymphomas with concurrent MYC and BCL2 abnormalities other than translocations behave similarly to MYC/BCL2 double-hit lymphomas. Mod. Pathol. Off. J. U. S. Can. Acad. Pathol. Inc. 2015, 28, 208-217. [CrossRef] [PubMed]

9. Collinge, B.; Ben-Neriah, S.; Chong, L.; Boyle, M.; Jiang, A.; Miyata-Takata, T.; Farinha, P.; Craig, J.W.; Slack, G.W.; Ennishi, D.; et al. The impact of MYC and BCL2 structural variants in tumors of DLBCL morphology and mechanisms of false-negative MYC IHC. Blood 2021, 137, 2196-2208. [CrossRef] [PubMed]

10. Horn, H.; Ziepert, M.; Becher, C.; Barth, T.F.E.; Bernd, H.-W.; Feller, A.C.; Klapper, W.; Hummel, M.; Stein, H.; Hansmann, M.-L.; et al. MYC status in concert with BCL2 and BCL6 expression predicts outcome in diffuse large B-cell lymphoma. Blood 2013, 121, 2253-2263. [CrossRef] [PubMed]

11. Dong, Y.; Tu, R.; Liu, H.; Qing, G. Regulation of cancer cell metabolism: Oncogenic MYC in the driver's seat. Signal Transduct. Target. Ther. 2020, 5, 124. [CrossRef]

12. Bahr, C.; von Paleske, L.; Uslu, V.V.; Remeseiro, S.; Takayama, N.; Ng, S.W.; Murison, A.; Langenfeld, K.; Petretich, M.; Scognamiglio, R.; et al. A Myc enhancer cluster regulates normal and leukaemic haematopoietic stem cell hierarchies. Nature 2018, 553, 515-520. [CrossRef]

13. Cho, S.W.; Xu, J.; Sun, R.; Mumbach, M.R.; Carter, A.C.; Chen, Y.G.; Yost, K.E.; Kim, J.; He, J.; Nevins, S.A.; et al. Promoter of lncRNA Gene PVT1 Is a Tumor-Suppressor DNA Boundary Element. Cell 2018, 173, 1398-1412.e1322. [CrossRef]

14. Sesques, P.; Johnson, N.A. Approach to the diagnosis and treatment of high-grade B-cell lymphomas with MYC and BCL2 and/or BCL6 rearrangements. Blood 2017, 129, 280-288. [CrossRef]

15. Bahram, F.; von der Lehr, N.; Cetinkaya, C.; Larsson, L.G. c-Myc hot spot mutations in lymphomas result in inefficient ubiquitination and decreased proteasome-mediated turnover. Blood 2000, 95, 2104-2110. [CrossRef]

16. Jiang, J.; Wang, J.; Yue, M.; Cai, X.; Wang, T.; Wu, C.; Su, H.; Wang, Y.; Han, M.; Zhang, Y.; et al. Direct Phosphorylation and Stabilization of MYC by Aurora B Kinase Promote T-cell Leukemogenesis. Cancer Cell 2020, 37, 200-215.e205. [CrossRef] [PubMed]

17. Herrera, A.F.; Mei, M.; Low, L.; Kim, H.T.; Griffin, G.K.; Song, J.Y.; Merryman, R.W.; Bedell, V.; Pak, C.; Sun, H.; et al. Relapsed or Refractory Double-Expressor and Double-Hit Lymphomas Have Inferior Progression-Free Survival After Autologous Stem-Cell Transplantation. J. Clin. Oncol. Off. J. Am. Soc. Clin. Oncol. 2017, 35, 24-31. [CrossRef] 
18. Miura, K.; Takahashi, H.; Nakagawa, M.; Izu, A.; Sugitani, M.; Kurita, D.; Sakagami, M.; Ohtake, S.; Uchino, Y.; Hojo, A.; et al. Clinical significance of co-expression of MYC and BCL2 protein in aggressive B-cell lymphomas treated with a second line immunochemotherapy. Leuk. Lymphoma 2016, 57, 1335-1341. [CrossRef] [PubMed]

19. Abdulla, M.; Laszlo, S.; Triumf, J.; Hedstrom, G.; Berglund, M.; Enblad, G.; Amini, R.M. A population-based study of cellular markers in R-CHOP treated diffuse large B-cell lymphoma patients. Acta Oncol. 2016, 55, 1126-1131. [CrossRef] [PubMed]

20. Johnson, N.A.; Slack, G.W.; Savage, K.J.; Connors, J.M.; Ben-Neriah, S.; Rogic, S.; Scott, D.W.; Tan, K.L.; Steidl, C.; Sehn, L.H.; et al. Concurrent expression of MYC and BCL2 in diffuse large B-cell lymphoma treated with rituximab plus cyclophosphamide, doxorubicin, vincristine, and prednisone. J. Clin. Oncol. Off. J. Am. Soc. Clin. Oncol. 2012, 30, 3452-3459. [CrossRef] [PubMed]

21. Ye, Q.; Xu-Monette, Z.Y.; Tzankov, A.; Deng, L.; Wang, X.; Manyam, G.C.; Visco, C.; Montes-Moreno, S.; Zhang, L.; Dybkaer, K.; et al. Prognostic impact of concurrent MYC and BCL6 rearrangements and expression in de novo diffuse large B-cell lymphoma. Oncotarget 2016, 7, 2401-2416. [CrossRef]

22. Peña, C.; Villegas, P.; Cabrera, M.E. Double or triple-expressor lymphomas: Prognostic impact of immunohistochemistry in patients with diffuse large B-cell lymphoma. Hematol. Transfus. Cell Ther. 2020, 42, 192-193. [CrossRef]

23. Wawire, J.; Sayed, S.; Moloo, Z.; Sohani, A.R. Diffuse Large B-Cell Lymphoma in Kenya: MYC, BCL2, and the Cell of Origin. J. Glob. Oncol. 2019, 5, 1-8. [CrossRef]

24. Han, B.; Kim, S.; Koh, J.; Yim, J.; Lee, C.; Heo, D.S.; Kim, T.M.; Paik, J.H.; Jeon, Y.K. Immunophenotypic Landscape and Prognosis of Diffuse Large B-Cell Lymphoma with MYC/BCL2 Double Expression: An Analysis of A Prospectively Immunoprofiled Cohort. Cancers 2020, 12, 3305. [CrossRef]

25. Moher, D.; Liberati, A.; Tetzlaff, J.; Altman, D.G. Preferred reporting items for systematic reviews and meta-analyses: The PRISMA statement. Ann. Intern. Med. 2009, 151, 264-269.w264. [CrossRef]

26. Donzelli, G.; Llopis-Gonzalez, A.; Llopis-Morales, A.; Cioni, L.; Morales-Suárez-Varela, M. Particulate Matter Exposure and Attention-Deficit/Hyperactivity Disorder in Children: A Systematic Review of Epidemiological Studies. Int. J. Environ. Res. Public Health 2019, 17, 67. [CrossRef] [PubMed]

27. Wells, G.A.; Shea, B.; O'Connell, D.; Peterson, J.; Welch, V.; Losos, M.; Tugwell, P. The Newcastle-Ottawa Scale (NOS) for Assessing the Quality if Nonrandomized Studies in Meta-Analyses. Available online: http://www.ohri.ca/programs/clinical_ epidemiology / oxford.asp (accessed on 6 June 2020).

28. DerSimonian, R.; Laird, N. Meta-analysis in clinical trials. Control. Clin. Trials 1986, 7, 177-188. [CrossRef]

29. Suh, C.H.; Park, S.H. Successful Publication of Systematic Review and Meta-Analysis of Studies Evaluating Diagnostic Test Accuracy. Korean J. Radiol. 2016, 17, 5-6. [CrossRef]

30. Higgins, J.P.; Thompson, S.G.; Deeks, J.J.; Altman, D.G. Measuring inconsistency in meta-analyses. BMJ 2003, 327, 557-560. [CrossRef]

31. Egger, M.; Davey Smith, G.; Schneider, M.; Minder, C. Bias in meta-analysis detected by a simple, graphical test. BMJ 1997, 315, 629-634. [CrossRef]

32. Wang, J.; Zhou, M.; Xu, J.-Y.; Chen, B.; Ouyang, J. Combination of BCL-2 and MYC protein expression improves high-risk stratification in diffuse large B-cell lymphoma. Onco Targets Ther. 2015, 8, 2645-2650. [CrossRef]

33. Barraclough, A.; Alzahrani, M.; Ettrup, M.S.; Bishton, M.; van Vliet, C.; Farinha, P.; Gould, C.; Birch, S.; Sehn, L.H.; Sovani, V.; et al. COO and MYC/BCL2 status do not predict outcome among patients with stage I/II DLBCL: A retrospective multicenter study. Blood Adv. 2019, 3, 2013-2021. [CrossRef]

34. Corobea, A.B.; Evsei, A.; Rosianu, C.; Gheorghe, M.; Birceanu, G.; Copca, N.; Sajin, M.; Lupu, A. The survival impact of combined expression of MYC, BCL2 and BCL6 in diffuse large B cell lymphoma patients. Arch. Balk. Med. Union 2018, 53, 232-238. [CrossRef]

35. Clark Schneider, K.M.; Banks, P.M.; Collie, A.M.; Lanigan, C.P.; Manilich, E.; Durkin, L.M.; Hill, B.T.; Hsi, E.D. Dual expression of MYC and BCL2 proteins predicts worse outcomes in diffuse large B-cell lymphoma. Leuk. Lymphoma 2016, 57, 1640-1648. [CrossRef]

36. Fogliatto, L.; Grokoski, K.C.; Strey, Y.M.; Vanelli, T.; Fraga, C.; Barra, M.B.; Pinto, F.C.; Bendit, I.; Bica, C.G. Prognostic impact of MYD88 mutation, proliferative index and cell origin in diffuse large B cell lymphoma. Hematol. Transfus. Cell Ther. 2019, 41, 50-56. [CrossRef]

37. Friedberg, J.W.; Unger, J.M.; Burack, W.R.; Gopal, A.K.; Raju, R.N.; Nademanee, A.P.; Kaminski, M.S.; Li, H.; Press, O.W.; Miller, T.P.; et al. R-CHOP with iodine-131 tositumomab consolidation for advanced stage diffuse large B-cell lymphoma (DLBCL): SWOG S0433. Br. J. Haematol. 2014, 166, 382-389. [CrossRef]

38. Hori, Y.; Yamamoto, H.; Nozaki, Y.; Torisu, T.; Fujiwara, M.; Taguchi, K.; Nishiyama, K.; Nakamura, S.; Kitazono, T.; Oda, Y. Colorectal diffuse large B-cell lymphoma: Molecular subclassification and prognostic significance of immunoglobulin gene translocation. Hum. Pathol. 2020, 96, 67-78. [CrossRef]

39. Jesionek-Kupnicka, D.; Braun, M.; Robak, T.; Kuncman, W.; Kordek, R. A large single-institution retrospective analysis of aggressive B-cell lymphomas according to the 2016/2017 WHO classification. Adv. Clin. Exp. Med. Off. Organ Wroc. Med. Univ. 2019, 28, 1359-1365. [CrossRef]

40. Jovanovic, M.P.; Mihaljevic, B.; Jakovic, L.; Martinovic, V.C.; Fekete, M.D.; Andjelic, B.; Antic, D.; Bogdanovic, A.; Boricic, N.; Terzic, T.; et al. BCL2 positive and BCL6 negative diffuse large B cell lymphoma patients benefit from R-CHOP therapy irrespective of germinal and non germinal center B cell like subtypes. J. BUON Off. J. Balk. Union Oncol. 2015, 20, 820-828. 
41. Klanova, M.; Sehn, L.H.; Bence-Bruckler, I.; Cavallo, F.; Jin, J.; Martelli, M.; Stewart, D.; Vitolo, U.; Zaja, F.; Zhang, Q.; et al. Integration of cell of origin into the clinical CNS International Prognostic Index improves CNS relapse prediction in DLBCL. Blood 2019, 133, 919-926. [CrossRef] [PubMed]

42. Li, L.; Zhang, X.; Zhang, T.; Song, Z.; Hu, G.; Li, W.; Li, L.; Qiu, L.; Qian, Z.; Zhou, S.; et al. Prognostic Significance of BCL-2 and BCL-6 Expression in MYC-positive DLBCL. Clin. Lymphoma Myeloma Leuk. 2018, 18, e381-e389. [CrossRef] [PubMed]

43. Li, M.; Liu, Y.; Wang, Y.; Chen, G.; Chen, Q.; Xiao, H.; Liu, F.; Qi, C.; Yu, Z.; Li, X.; et al. Anaplastic Variant of Diffuse Large B-cell Lymphoma Displays Intricate Genetic Alterations and Distinct Biological Features. Am. J. Surg. Pathol. 2017, 41, 1322-1332. [CrossRef]

44. Liu, Y.; Yu, K.; Li, M.; Zeng, K.; Wei, J.; Li, X.; Liu, Y.; Zhao, D.; Fan, L.; Yu, Z.; et al. EZH2 overexpression in primary gastrointestinal diffuse large B-cell lymphoma and its association with the clinicopathological features. Hum. Pathol. 2017, 64, 213-221. [CrossRef]

45. Lu, T.X.; Fan, L.; Wang, L.; Wu, J.Z.; Miao, K.R.; Liang, J.H.; Gong, Q.X.; Wang, Z.; Young, K.H.; Xu, W.; et al. MYC or BCL2 copy number aberration is a strong predictor of outcome in patients with diffuse large B-cell lymphoma. Oncotarget 2015, 6, 18374-18388. [CrossRef]

46. Ma, Z.; Niu, J.; Cao, Y.; Pang, X.; Cui, W.; Zhang, W.; Li, X. Clinical significance of 'double-hit' and 'double-expression' lymphomas. J. Clin. Pathol. 2020, 73, 126-138. [CrossRef]

47. Mohammed, A.A.; Rashed, H.E.; Abdelrahman, A.E.; Obaya, A.A.; Toam, M.; Abdel Nour, H.M.; Abdelhamid, M.I.; Elsayed, F.M. C-MYC and BCL2: Correlation between Protein Over-Expression and Gene Translocation and Impact on Outcome in Diffuse Large B Cell Lymphoma. Asian Pac. J. Cancer Prev. APJCP 2019, 20, 1463-1470. [CrossRef]

48. Molina, T.J.; Canioni, D.; Copie-Bergman, C.; Recher, C.; Briere, J.; Haioun, C.; Berger, F.; Ferme, C.; Copin, M.C.; Casasnovas, O.; et al. Young patients with non-germinal center B-cell-like diffuse large B-cell lymphoma benefit from intensified chemotherapy with ACVBP plus rituximab compared with CHOP plus rituximab: Analysis of data from the Groupe d'Etudes des Lymphomes de l'Adulte/lymphoma study association phase III trial LNH 03-2B. J. Clin. Oncol. Off. J. Am. Soc. Clin. Oncol. 2014, 32, 3996-4003. [CrossRef]

49. Na, H.Y.; Choe, J.Y.; Shin, S.A.; Kim, H.J.; Han, J.H.; Kim, H.K.; Oh, S.H.; Kim, J.E. Characteristics of CD5-positive diffuse large B-cell lymphoma among Koreans: High incidence of BCL2 and MYC double-expressors. PLoS ONE 2019, 14, e0224247. [CrossRef] [PubMed]

50. Pedersen, M.O.; Gang, A.O.; Brown, P.; Pedersen, M.; Knudsen, H.; Nielsen, S.L.; Poulsen, T.; Wirenfeldt Klausen, T.; Hogdall, E.; Norgaard, P. Real world data on young patients with high-risk diffuse large B-cell lymphoma treated with R-CHOP or R-CHOEP-MYC, BCL2 and BCL6 as prognostic biomarkers. PLoS ONE 2017, 12, e0186983. [CrossRef]

51. Peroja, P.; Pedersen, M.; Mantere, T.; Norgaard, P.; Peltonen, J.; Haapasaari, K.M.; Bohm, J.; Jantunen, E.; Turpeenniemi-Hujanen, T.; Rapakko, K.; et al. Mutation of TP53, translocation analysis and immunohistochemical expression of MYC, BCL-2 and BCL-6 in patients with DLBCL treated with R-CHOP. Sci. Rep. 2018, 8, 14814. [CrossRef]

52. Perry, A.M.; Alvarado-Bernal, Y.; Laurini, J.A.; Smith, L.M.; Slack, G.W.; Tan, K.L.; Sehn, L.H.; Fu, K.; Aoun, P.; Greiner, T.C.; et al. MYC and BCL2 protein expression predicts survival in patients with diffuse large B-cell lymphoma treated with rituximab. Br. J. Haematol. 2014, 165, 382-391. [CrossRef] [PubMed]

53. Petrella, T.; Copie-Bergman, C.; Briere, J.; Delarue, R.; Jardin, F.; Ruminy, P.; Thieblemont, C.; Figeac, M.; Canioni, D.; Feugier, P.; et al. BCL2 expression but not MYC and BCL2 coexpression predicts survival in elderly patients with diffuse large B-cell lymphoma independently of cell of origin in the phase 3 LNH03-6B trial. Ann. Oncol. Off. J. Eur. Soc. Med. Oncol. 2017, 28, 1042-1049. [CrossRef]

54. Phang, K.C.; Hussin, N.H.; Abdul Rahman, F.; Tizen, N.M.S.; Mansoor, A.; Masir, N. Characterisation of immunogenotypes of diffuse large B-cell lymphoma. Malays. J. Pathol. 2019, 41, 101-124.

55. Rajnai, H.; Heyning, F.H.; Koens, L.; Sebestyen, A.; Andrikovics, H.; Hogendoorn, P.C.; Matolcsy, A.; Szepesi, A. The density of CD8+ T-cell infiltration and expression of BCL2 predicts outcome of primary diffuse large B-cell lymphoma of bone. Virchows Arch. Int. J. Pathol. 2014, 464, 229-239. [CrossRef]

56. Scott, D.W.; Mottok, A.; Ennishi, D.; Wright, G.W.; Farinha, P.; Ben-Neriah, S.; Kridel, R.; Barry, G.S.; Hother, C.; Abrisqueta, P.; et al. Prognostic Significance of Diffuse Large B-Cell Lymphoma Cell of Origin Determined by Digital Gene Expression in Formalin-Fixed Paraffin-Embedded Tissue Biopsies. J. Clin. Oncol. Off. J. Am. Soc. Clin. Oncol. 2015, 33, 2848-2856. [CrossRef]

57. Sha, C.; Barrans, S.; Cucco, F.; Bentley, M.A.; Care, M.A.; Cummin, T.; Kennedy, H.; Thompson, J.S.; Uddin, R.; Worrillow, L.; et al. Molecular High-Grade B-Cell Lymphoma: Defining a Poor-Risk Group That Requires Different Approaches to Therapy. J. Clin. Oncol. Off. J. Am. Soc. Clin. Oncol. 2019, 37, 202-212. [CrossRef]

58. Staiger, A.M.; Ziepert, M.; Horn, H.; Scott, D.W.; Barth, T.F.E.; Bernd, H.W.; Feller, A.C.; Klapper, W.; Szczepanowski, M.; Hummel, M.; et al. Clinical Impact of the Cell-of-Origin Classification and the MYC/BCL2 Dual Expresser Status in Diffuse Large B-Cell Lymphoma Treated Within Prospective Clinical Trials of the German High-Grade Non-Hodgkin's Lymphoma Study Group. J. Clin. Oncol. Off. J. Am. Soc. Clin. Oncol. 2017, 35, 2515-2526. [CrossRef]

59. Suresh, B.; Asati, V.; Lakshmaiah, K.C.; Babu, G.; Lokanatha, D.; Jacob, L.A.; Lokesh, K.N.; Rudresh, A.H.; Rajeev, L.K.; Smitha, S.; et al. Primary gastrointestinal diffuse large B-cell lymphoma: A prospective study from South India. South Asian J. Cancer 2019, 8 , 57-59. [CrossRef] 
60. Takahashi, H.; Miura, K.; Nakagawa, M.; Sugitani, M.; Amano, Y.; Kurita, D.; Sakagami, M.; Ohtake, S.; Uchino, Y.; Kodaira, H.; et al. Negative impact of concurrent overexpression of MYC and BCL2 in patients with advanced diffuse large B-cell lymphoma treated with dose-intensified immunochemotherapy. Leuk. Lymphoma 2016, 57, 2784-2790. [CrossRef]

61. Teoh, C.S.; Lee, S.Y.; Chiang, S.K.; Chew, T.K.; Goh, A.S. Impact of Double Expression of C-MYC/BCL2 Protein and Cell of Origin Subtypes on the Outcome among Patients with Diffuse Large B-Cell Lymphoma: A Single Asian Center Experience. Asian Pac. J. Cancer Prev. APJCP 2018, 19, 1229-1236. [CrossRef] [PubMed]

62. Tessier-Cloutier, B.; Twa, D.D.; Baecklund, E.; Gascoyne, R.; Johnson, N.A.; Backlin, C.; Kamen, D.L.; Clarke, A.E.; RamseyGoldman, R.; Lee, J.L.; et al. Cell of origin in diffuse large B-cell lymphoma in systemic lupus erythematosus: Molecular and clinical factors associated with survival. Lupus Sci. Med. 2019, 6, e000324. [CrossRef]

63. Ting, C.Y.; Chang, K.M.; Kuan, J.W.; Sathar, J.; Chew, L.P.; Wong, O.J.; Yusuf, Y.; Wong, L.; Samsudin, A.T.; Pana, M.; et al. Clinical Significance of BCL2, C-MYC, and BCL6 Genetic Abnormalities, Epstein-Barr Virus Infection, CD5 Protein Expression, Germinal Center B Cell/Non-Germinal Center B-Cell Subtypes, Co-expression of MYC/BCL2 Proteins and Co-expression of MYC/BCL2/BCL6 Proteins in Diffuse Large B-Cell Lymphoma: A Clinical and Pathological Correlation Study of 120 Patients. Int. J. Med. Sci. 2019, 16, 556-566. [CrossRef]

64. Wang, X.J.; Medeiros, L.J.; Bueso-Ramos, C.E.; Tang, G.; Wang, S.; Oki, Y.; Desai, P.; Khoury, J.D.; Miranda, R.N.; Tang, Z.; et al. P53 expression correlates with poorer survival and augments the negative prognostic effect of MYC rearrangement, expression or concurrent MYC/BCL2 expression in diffuse large B-cell lymphoma. Mod. Pathol. Off. J. U. S. Can. Acad. Pathol. Inc. 2017, 30, 194-203. [CrossRef] [PubMed]

65. Xia, B.; Zhang, L.; Guo, S.Q.; Li, X.W.; Qu, F.L.; Zhao, H.F.; Zhang, L.Y.; Sun, B.C.; You, J.; Zhang, Y.Z. Coexpression of MYC and BCL-2 predicts prognosis in primary gastrointestinal diffuse large B-cell lymphoma. World J. Gastroenterol. 2015, 21, 2433-2442. [CrossRef] [PubMed]

66. Xie, Y.; Bulbul, M.A.; Ji, L.; Inouye, C.M.; Groshen, S.G.; Tulpule, A.; O’Malley, D.P.; Wang, E.; Siddiqi, I.N. p53 expression is a strong marker of inferior survival in de novo diffuse large B-cell lymphoma and may have enhanced negative effect with MYC coexpression: A single institutional clinicopathologic study. Am. J. Clin. Pathol. 2014, 141, 593-604. [CrossRef]

67. Xu, P.P.; Zhong, H.J.; Huang, Y.H.; Gao, X.D.; Zhao, X.; Shen, Y.; Cheng, S.; Huang, J.Y.; Chen, S.J.; Wang, L.; et al. B-cell Function Gene Mutations in Diffuse Large B-cell Lymphoma: A Retrospective Cohort Study. EBioMedicine 2017, 16, 106-114. [CrossRef] [PubMed]

68. Yan, L.X.; Liu, Y.H.; Luo, D.L.; Zhang, F.; Cheng, Y.; Luo, X.L.; Xu, J.; Cheng, J.; Zhuang, H.G. MYC expression in concert with BCL2 and BCL6 expression predicts outcome in Chinese patients with diffuse large B-cell lymphoma, not otherwise specified. PLoS ONE 2014, 9, e104068. [CrossRef]

69. Zhang, Y.; Wang, H.; Ren, C.; Yu, H.; Fang, W.; Zhang, N.; Gao, S.; Hou, Q. Correlation Between C-MYC, BCL-2, and BCL-6 Protein Expression and Gene Translocation as Biomarkers in Diagnosis and Prognosis of Diffuse Large B-cell Lymphoma. Front. Pharmacol. 2018, 9, 1497. [CrossRef] [PubMed]

70. Ennishi, D.; Jiang, A.; Boyle, M.; Collinge, B.; Grande, B.M.; Ben-Neriah, S.; Rushton, C.; Tang, J.; Thomas, N.; Slack, G.W.; et al. Double-Hit Gene Expression Signature Defines a Distinct Subgroup of Germinal Center B-Cell-Like Diffuse Large B-Cell Lymphoma. J. Clin. Oncol. Off. J. Am. Soc. Clin. Oncol. 2019, 37, 190-201. [CrossRef] [PubMed]

71. Nguyen, H.; Perry, A.; Skrabek, P.; Nasr, M.; Herrera, A.F.; Bedell, V.; Murata-Collins, J.; Pillai, R.; Xu, M.; Chen, L.; et al. Validation of the Double-Hit Gene Expression Signature (DLBCL90) in an Independent Cohort of Patients with Diffuse Large B-Cell Lymphoma of Germinal Center Origin. J. Mol. Diagn. JMD 2021, 23, 658-664. [CrossRef]

72. Isaksen, K.T.; Beiske, K.; Smeland, E.B.; Jørgensen, J.; Brodtkorb, M.; Myklebust, J.H.; Jerkeman, M.; Meriranta, L.; KarjalainenLindsberg, M.-L.; Leppä, S.; et al. The DLBCL90 gene-expression assay identifies double-hit lymphomas with high sensitivity in patients from two phase II clinical trials with high-risk diffuse large B-cell lymphoma. eJHaem 2021, 2, 107-111. [CrossRef]

73. Riedell, P.A.; Smith, S.M. Double hit and double expressors in lymphoma: Definition and treatment. Cancer 2018, 124, 4622-4632. [CrossRef]

74. Scott, D.W.; King, R.L.; Staiger, A.M.; Ben-Neriah, S.; Jiang, A.; Horn, H.; Mottok, A.; Farinha, P.; Slack, G.W.; Ennishi, D.; et al. High-grade B-cell lymphoma with MYC and BCL2 and/or BCL6 rearrangements with diffuse large B-cell lymphoma morphology. Blood 2018, 131, 2060-2064. [CrossRef] [PubMed]

75. Schraders, M.; de Jong, D.; Kluin, P.; Groenen, P.; van Krieken, H. Lack of Bcl-2 expression in follicular lymphoma may be caused by mutations in the BCL2 gene or by absence of the $t(14 ; 18)$ translocation. J. Pathol. 2005, 205, 329-335. [CrossRef]

76. Hilton, L.K.; Tang, J.; Ben-Neriah, S.; Alcaide, M.; Jiang, A.; Grande, B.M.; Rushton, C.K.; Boyle, M.; Meissner, B.; Scott, D.W.; et al. The double-hit signature identifies double-hit diffuse large B-cell lymphoma with genetic events cryptic to FISH. Blood 2019, 134, 1528-1532. [CrossRef] [PubMed]

77. Shenoy, P.J.; Malik, N.; Nooka, A.; Sinha, R.; Ward, K.C.; Brawley, O.W.; Lipscomb, J.; Flowers, C.R. Racial differences in the presentation and outcomes of diffuse large B-cell lymphoma in the United States. Cancer 2011, 117, 2530-2540. [CrossRef] [PubMed]

78. Chen, Y.; Han, T.; Iqbal, J.; Irons, R.; Chan, W.C.; Zhu, X.; Fu, K. Diffuse large B-cell lymphoma in Chinese patients: Immunophenotypic and cytogenetic analyses of 124 cases. Am. J. Clin. Pathol. 2010, 133, 305-313. [CrossRef] 
79. Hu, S.; Xu-Monette, Z.Y.; Tzankov, A.; Green, T.; Wu, L.; Balasubramanyam, A.; Liu, W.M.; Visco, C.; Li, Y.; Miranda, R.N.; et al. $\mathrm{MYC} / \mathrm{BCL} 2$ protein coexpression contributes to the inferior survival of activated B-cell subtype of diffuse large B-cell lymphoma and demonstrates high-risk gene expression signatures: A report from The International DLBCL Rituximab-CHOP Consortium Program. Blood 2013, 121, 4021-4031. [CrossRef]

80. Li, L.; Li, Y.; Que, X.; Gao, X.; Gao, Q.; Yu, M.; Ma, K.; Xi, Y.; Wang, T. Prognostic significances of overexpression MYC and/or BCL2 in R-CHOP-treated diffuse large B-cell lymphoma: A Systematic review and meta-analysis. Sci. Rep. 2018, 8, 6267. [CrossRef]

81. Ambrosio, M.R.; Lazzi, S.; Bello, G.L.; Santi, R.; Porro, L.D.; de Santi, M.M.; Guazzo, R.; Mundo, L.; Rigacci, L.; Kovalchuck, S.; et al. MYC protein expression scoring and its impact on the prognosis of aggressive B-cell lymphoma patients. Haematologica 2019, 104, e25-e28. [CrossRef] [PubMed]

82. Ziepert, M.; Lazzi, S.; Santi, R.; Vergoni, F.; Granai, M.; Mancini, V.; Staiger, A.; Horn, H.; Löffler, M.; Pöschel, V.; et al. A 70\% cut-off for MYC protein expression in diffuse large B cell lymphoma identifies a high-risk group of patients. Haematologica 2020, 105, 2667-2670. [CrossRef] [PubMed]

83. Bosch, M.; Akhter, A.; Chen, B.E.; Mansoor, A.; Lebrun, D.; Good, D.; Crump, M.; Shepherd, L.; Scott, D.W.; Stewart, D.A. A bioclinical prognostic model using MYC and BCL2 predicts outcome in relapsed/refractory diffuse large B-cell lymphoma. Haematologica 2018, 103, 288-296. [CrossRef] [PubMed]

84. Allen, J.; Ruano Mendez, A.L.; Rybicki, L.; Sawalha, Y.; Jagadeesh, D.; Dean, R.; Pohlman, B.; Smith, M.R.; Hsi, E.D.; Hill, B.T. Co-expression of MYC and BCL2 predicts poorer outcomes for relapsed/refractory diffuse large B-cell lymphoma with R-ICE and intent to transplant. Ther. Adv. Hematol. 2018, 9, 81-87. [CrossRef] [PubMed] 